Tor Atle Rosness (f. 1976) er medisinsk redaktør i Tidsskriftet, sykehjemslege i Bærum kommune og førsteamanuensis ved Lovisenberg Diakonale Høgskole.

\title{
Glemsk og glemt
}

På tampen av 2016 kom nyheten om at solanezumab ikke innfridde forventningene om å være en effektiv behandling av Alzheimers sykdom. Nå følger et annet medikament, verubecestat, etter i rekken av skuffelser (1). Begge medisinene reduserer opphopningen av amyloide plakk i hjernen og var en del av forventningene om å kunne bremse sykdomsutviklingen på et tidlig stadium. For fem år siden ble det påpekt på lederplass i Tidsskriftet at behandlingen av demens var lite effektiv (2). Med disse nedslående resultatene stemmer utsagnet fremdeles: Fortsatt finnes det ikke medisiner som forebygger eller i stor grad bremser sykdomsutviklingen. Problemene med å finne effektiv behandling kan delvis skyldes at de kliniske symptomene hos pasienter med demens ikke nødvendigvis korresponderer med graden av hjernesvinn. Og reduksjon av mengden av plakk i hjernen gir ikke alene bedre hukommelse (3).

I korte trekk finnes det i dag følgende behandlingstilbud ved demens: fire antidemensmedisiner, antidepressiver, antipsykotika, fysisk aktivitet, miljøtiltak, pårørendegrupper, dagsentre, støttekontakter, avlastningsopphold og ulike institusjonsplasser (4). Dette er gode tilbud. Det er bare det at ingenting av dette er verken nytt eller veldig effektivt. Dessuten blir pasienter med demens verre over tid og de ulike tilbudene således mindre relevante etter hvert som sykdommen progredierer. Det er derfor et klart behov for bedre behandlingsmuligheter enn de som allerede finnes.

Men etter flere mislykkede farmasøytiske forsøk virker det som om en kurativ behandling for øyeblikket er uoppnåelig. Det gjør det lett å tenke at det i klinisk praksis ikke er nødvendig å stille demensdiagnoser - spesielt ikke på et tidlig stadium - fordi det ikke finnes effektive måter å behandle sykdommen på. Dette er gjenkjennbare holdninger i min egen hverdag som sykehjemslege. Og ikke bare der, for ifølge en norsk studie med 1000 deltagere fra 19 kommuner blir kun én av fem med demens diagnostisert (5). Men når et menneske, selv en i 80-årene, begynner å glemme i den grad at det påvirker evnen til å fungere i hverdagen, bør han eller hun etter min mening alltid utredes for demens. Både pasient og pårørende trenger en avklaring av situasjonen. En diagnose kan gjøre at eldre med demens vil få bedre behandling og at bruken av tvang reduseres, som vist av svenske kolleger (6).

For travle leger i klinisk praksis, enten det er i sykehjem, på fastlegekontor eller i sykehus, forblir utredning av demens ofte, forståelig nok, altså nedprioritert. For demensforskere er situasjonen en annen. I år gikk demensforskningsprisen fra Nasjonalforeningen for folkehelsen til professor Tormod Fladby (7). Han har forsket på biomarkører fra blod og spinalvæske som gir mulighet til å stille dia- gnosen før demenstilstanden blir mulig å oppdage klinisk. Dermed kan man håpe på å komme tidligere i gang med behandling (8).

Slik kunnskap kan i teorien gjøre det mulig å forutsi hvorvidt en person er utsatt for å få demens - flere år før symptomene oppstår (8). Men hvilke biomarkører som har størst prognostisk betydning, er det ennå ikke enighet om (9). Dette gir etiske problemer knyttet til det å stille diagnosen i en tidlig fase. Så lenge det ikke finnes muligheter for å forebygge tilstanden, kan kunnskap om fremtidig alvorlig sykdom i verste fall være mer til skade enn til gagn. Dette kompliseres ytterligere av at overlappingen mellom normal aldring og demens ikke er så entydig som tidligere antatt (10).

Hjerneforskning, inkludert forskning på hukommelse og demens, har høy anseelse både blant forskere og i samfunnet ellers. Men det er et paradoks at utredning og behandling av demenssykdommer langt fra har samme status. Inntil vi forhåpentligvis klarer å utvikle mer effektive medikamenter, må vi alle, enten vi er forskere eller klinikere, ikke glemme å diagnostisere, informere, ivareta og, så langt det lar seg gjøre, behandle denne pasientgruppen.

Vi skal ikke glemme de glemske.

\section{Litteratur}

1. Key Alzheimer's drug show virtually no chance of working. www.newscientist.com/article/2121497-key-alzheimers-drug-shows-virtually-no-chance-ofworking/ (27.1.2017).

2. Brean A. Når hjernen svikter. Tidsskr Nor Legeforen 2011; 121: 2227.

3. Sperling RA, Aisen PS, Beckett LA et al. Toward defining the preclinical stages of Alzheimer's disease: recommendations from the National Institute on AgingAlzheimer's Association workgroups on diagnostic guidelines for Alzheimer's disease. Alzheimers Dement 2011; 7: 280-92.

4. Laver K, Dyer S, Whitehead C et al. Interventions to delay functional decline in people with dementia: a systematic review of systematic reviews. BMJ Open 2016; 6: e010767.

5. Wergeland JN, Selbæk G, Høgset LD et al. Dementia, neuropsychiatric symptoms, and the use of psychotropic drugs among older people who receive domiciliary care: a cross-sectional study. Int Psychogeriatr 2014; 26: 383-91.

6. Pellfolk T, Sandman PO, Gustafson Y et al. Physical restraint use in institutional care of old people in Sweden in 2000 and 2007. Int Psychogeriatr 2012; 24: 1144-52.

7. Demensforsker og hjerteforsker hedres av Kong Harald. https://www.budstikka.no/ demens/hjerteinfarkt/sykdom/demensforsker-og-hjerteforsker-hedres-av-kongharald/s/5-55-436354 (27.2.2017)

8. Dubois $\mathrm{B}$, Feldman $\mathrm{HH}$, Jacova $\mathrm{C}$ et al. Advancing research diagnostic criteria for Alzheimer's disease: the IWG-2 criteria. Lancet Neurol 2014; 13: 614-29.

9. Olsson B, Lautner R, Andreasson U et al. CSF and blood biomarkers for the diagnosis of Alzheimer's disease: a systematic review and meta-analysis. Lancet Neurol 2016; 15: 673-84.

10. Mattsson N, Zetterberg H, Janelidze S et al. Plasma tau in Alzheimer disease. Neurology 2016; 87: 1827-35. 